\title{
Socio-economic status and personality of school going children
}

Received: 19.05.2016; Revised: 22.10.2016; Accepted: 03.11.2016

See end of the paper for authors' affiliations ONAM DAYAL

Department of Home Science, Hindu Degree College, MORADABAD (U.P.) INDIA

Email : onambbau@gmail.com
ABSTRACT : Effect of socio-economic status was studied on the personality factors of children. Respondents were 300 school going children of age 7 to 13 years belongs to different socio-economic groups. A fourteen factor personality inventory CPQ (1979) by S.D. Kapoor was used to determine the personality factors of children. For statistical analysis one way ANOVA was applied. The results showed a significant effect of socio-economic status on the personality factors of children.

KEY WORDS: Socio-economic status, Fourteen personality factors, Children personality questionnaire, Sizothymia, Affectothymia

- HOW TO CITE THIS PAPER : Dayal, Onam and Dayal, Neha (2016). Socio-economic status and personality of school going children. Asian J. Home Sci., 11 (2) : 387-393, DOI: 10.15740/HAS/AJHS/ 11.2/387-393. 